\title{
Effect of Psychological Ownership on Employee Silence and Task Performance: A Study on Academicians
}

\author{
Kültigin Akçin ${ }^{1}$, Serhat Erat ${ }^{1}$, Ümit Alniaçik ${ }^{2}$, Aydem B. Çiftçioğlu ${ }^{3}$ \\ ${ }^{1}$ Gebze Technical University, 41400, Gebze / Kocaeli, Turkey \\ ${ }^{2}$ Kocaeli University, 41380, Kocaeli, Turkey \\ ${ }^{3}$ Uludağ University, 16059, Bursa, Turkey \\ Correspondence: Kültigin AKÇİN, Gebze Technical University, Gebze, Kocaeli, Turkey.
}

Received: October 25, 2017

Accepted: November 17, 2017 Online Published: November 23, 2017

doi:10.5539/ibr.v11n1p34

URL: https://doi.org/10.5539/ibr.v11n1p34

\begin{abstract}
This study examines the effect of psychological ownership on employee silence and task performance. It aims to probe the relationship between psychological ownership (a relatively new concept in the literature) and employee silence and the effect of psychological ownership on task performance. Research data is collected from 502 academicians employed by state universities in Turkey. Exploratory factor analyses, correlation and regression analyses are performed to test a number of hypotheses. Data analyses revealed that, there is a negative relationship between psychological ownership and both acquiescent silence and defensive silence, while there is a positive relationship between psychological ownership and pro-social silence. Further, it is found that acquiescent silence and defensive silence have significantly negative effects on task performance, while pro-social silence exerts a statistically significant positive effect on task performance. Finally, psychological ownership is found to exert a statistically significant positive effect on task performance. Research and managerial implications of these findings are discussed in detail.
\end{abstract}

Keywords: employee silence, psychological ownership, task performance, defensive silence, acquiescent silence, pro-social silence

\section{Introduction}

Organizations' expectations to survive and gain competitive advantage in the business environment primarily depend on their employees' attitudes and behavior towards the work and the organization. Augmenting communication channels led employees to behave collectively rather than acting indi vidually in the organizational setting. The workplace environment is critical to motivate and influence employees to corroborate for organizational objectives. Organization's success and survival is determined by the extent of sharing the common organizational goals by management with the employees. Hence, management's ability to motivate employees and creating a we-feeling in the workplace is a key component of organizational success and a higher performance.

Psychological ownership provides employees with the feeling of embracing a common goal in the work place. The sense of possessiveness creates a feeling that the organization is 'mine' or 'ours' and motivates the employees to share the excitement (Van Dyne \& Pierce, 2004). According to Van Dyne and Pierce (2004) psychological ownership for the organization increases employee satisfaction and it is a significant predictor of employee attitudes and behavior in the workplace. It is quite obvious that the ownership feeling of employees is a significant contributor of competitive advantage of the organization.

On the other hand, employee dissatisfaction caused by organizational climate or the tough hierarchical structure may lead employees to keep silent and stay indifferent to identifying and resolving organizational problems. Employees' low self-confidence, perceived fear of communication and negative expectations about the outcomes of communicating may effect their silence or voice behavior in the workplace (Brinsfield et.al., 2009). As employees keep silent, identifying and resolving organizational problems will be difficult (Milliken et.al, 2003). This situation significantly influences both employee performance and organizational future. Employees are critical actors for organizational change, innovation and improvement and they influence organizational performance (Çakıcı, 2007). Rodgers (1998) stated that employees will have a strong organizational culture when they actively participate in decision making and undertake responsibilities of their job. From this point of view, we 
can argue that employees' ownership feelings can be reinforced when managers value their expectations ad opinions in the workplace. In a similar vein, $\mathrm{Li}$ and Ling (2010) argued that administrative support will decrease employee silence. When the employees perceive the support, their confidence to the management will increase and thus silence will decrease.

Psychological ownership, a relatively new concept in the literature, and employee silence can be significant predictors of employee task performance. Probing the potential effects of silence and ownership on task performance may provide important insights. Objective of the current study is examining these relationships in a particular context, where a prominent hierarchical structure exists: academicians working for the higher education institutions. Research examining the interrelations among employee silence, psychological ownership and task performance is relatively scarce in the extant literature. Hence, this study aims to fill this gap to some extent by examining the effect of psychological ownership and employee silence on task performance. Theoretical background and literature review is provided in the next section. Next, methods and analyses section is presented. Findings are discussed and implications are provided in the last section.

\section{Theoretical Background}

\subsection{Psychological Ownership}

Psychological ownership is the feeling of possession over an object, concept, organization, or other person that may or may not be supported by formal ownership. Pierce and Furo (1991) stated that there are three forms of ownership rights. These are the right of physical/financial possession, the right of control and the right to obtain information. Further, they argue that (1) ownership feeling is a part of self-definition, (2) people develop feelings of ownership towards a variety of tangible or intangible objects, and (3) ownership feeling has significant behavioral, emotional and psychological outcomes (Pierce et.al. 2001). This feeling can arise in the absence of any formal or legal claims of ownership (Mayhew et.al, 2007). According to Dittmar (1992), the feeling of "mine" or "ours" has an important role in defining an individual's self-identity. Pierce et.al (1991) found in their study about employee ownership, that psychological ownership is developed from formal ownership.

A theory of psychological ownership explaining the ownership as a state in which individuals feel as though the target of ownership (material or immaterial in nature) or a piece of it is "theirs" was developed by Pierce et.al (2001). This ownership feeling can be directed towards the organization, group, idea or job as well as the equipment (Van Dyne \& Pierce, 2004). Ownership invokes such positive feelings as satisfaction, volunteerism and personal sacrifice in the psychological ownership and organization relationship (Van Dyne \& Pierce, 2004). As a result of such positive feelings, psychological ownership will provide high motivation that creates extra role behavior (Pierce et.al. 1991). According to Sieger and others (2013); psychological ownership increases firm performance by influencing entrepreneurship at the individual level.

Although there is not any empirical research examining the relationship between psychological ownership and employee silence, some studies tell about the existence of such relationship. For example, Botero and Van Dyne (2009) found a positive relationship between the open communication channels in the organization and employees' ease of self-expression and feeling psychologically safe within the organization. From psychological ownership perspective, based on their ownership target, employees with a focus on development and others with a focus of prevention arouse different feelings. For example; since valuing information sharing may create change and development, a development focused administrator may find personal satisfaction in sharing proprietary information about a project that may contribute to growth of the company. On the other hand, prevention focused employees may withhold such information to keep their status and avoid change (Avey et.al, 2009). Vakola and Bouradas (2005) examining the relationship between organizational commitment, job satisfaction and silence behavior found that silence negatively effected organizational commitment and job satisfaction.

\subsection{Employee Silence}

According to Pinder and Harlos (2001), silence is an inherent state where the individual communicates with himself. According to Brinsfield et.al (2009) silence is a form of communication involving a range of cognitions, emotions and intentions. Pinder and Harlos (2001:334) defined employee silence as "the withholding of any form of genuine expression about the individual's behavioral, cognitive and/affective evaluations of his organizational circumstances to persons who are perceived to be capable of effecting change or redress. Many researchers assumed that silence is a relatively simple, unitary concept. There exist two main reasons of disregarding silence in past research. First, silence was taken as lack of voice (indeed it is not a behavior). When there is no conversation, lack of behavior does not draw attention. Second, it is hard to examine a lack of behavior compared to explicit behavior (Van Dyne et.al, 2003). Employee silence was first conceptualized by 
Hirschman in the management literature. Hirschman (1970) defined silence as a passive but constructive response synonymous with loyalty, and since then management scientists have continued to equate silence with loyalty. At first, silence was taken as lack of utterance showing approval or commitment, but then it was conceptualized as a behavior affecting organizational performance and employees (Çakıc1, 2007: 149).

Employee silence is depicted as withholding any form of genuine expression about the individual's behavioral, cognitive and/affective evaluations of his organizational circumstances to persons who are perceived to be capable of effecting change or redress (Pinder \& Harlos, 2001). While Morrison and Milliken (2000) take organizational silence as a negative behavior, Pinder and Harlos (2001) also see silent employees who deliberately withhold their evaluations about the organizational issues as harmful to themselves, to others or to the organization. Based on Morrison \& Milliken (2000) and Pinder \& Harlos's (2001) "Quiescent Silence" and "Acquiescence Silence" conceptualizations Van Dyne and others (2003) incorporated a third dimension (Pro-social Silence) to organizational silence concept.

Acquiescent Silence: Conceptualized by Pinder and Harlos (2001), acquiescent silence is defined as withholding relevant ideas, information, or opinions, based on resignation. Employees do not share their ideas and suggestions when they understand that they cannot make a difference (Van Dyne et.al, 2003).

Defensive Silence: Defensive silence is defined as withholding relevant ideas, information, or opinions as a form of self-protection, based on fear (Morrison and Milliken, 2000). It is an intentional and proactive behavior that is intended to protect the self from external threats. Van Dyne et.al (2003) defined defensive silence as preserving work-related information, ideas and opinions based on fear with the goal of protecting the self. Defensive Silence is intentional and proactive behavior that is intended to protect the self from external threats (Schlenker and Weigold, 1989). Defensive Silence is more proactive, involving awareness and consideration of alternatives compared to acquiescent silence and it is followed by a conscious decision to withhold ideas, information, and opinions as the best personal strategy at the moment (Van Dyne et.al, 2003).

Pro-social Silence: Pro-social Silence is defined as withholding work-related ideas, information, or opinions with the goal of benefiting other people or the organization - based on altruism or cooperative motives (Van Dyne et.al, 2003). Similar to defensive silence, pro-social silence is intentional and proactive behavior; it is not forced by the organization (Van Dyne et.al, 2003).

According to Morrison and Milliken (2003) administrators must create a psychologically safe work environment, enhance team learning and establish an open communication atmosphere in order to eliminate the barriers and motivate employees to speak up. Organizational silence often leads to increased negative emotions within the organization and decreases employee performance and effectiveness (Perlow \& Williams, 2003). Since employee performance is tied to their satisfaction, silent employees remain incapable of satisfying these needs (Murphy \& Cleveland, 1995).

\subsection{Task Performance}

In prominent studies dated back to 1970 's task performance is defined based on intentions and behavior, instead of their consequences. These definitions focused on environmentally restricted behavior in addition to self-controlled behavior of employees that may affect organizational performance. Job performance is defined as actions and behaviors that are under the control of the individual that contribute to the goals of the organization (Rotundo and Sackett, 2002). Borman and Motowidlo (1993) defined task performance as the first dimension of job performance and conceptualized it as the necessary responsibilities that are required to complete a task. Task performance is related to the technical and professional features of the job. According to Jawahar and Carr (2007) task performance depicts fixed duties and responsibilities that make a job differed from others. Task performance refers to behaviors and activities that support the organization's technical core, which can involve the execution of technical processes or the maintenance of those processes (Borman ve Motowidlo, 1997). Task performance should be largely a function of cognitive ability, mediated primarily by task knowledge (knowledge of principles related to technical aspects of job performance), task skill (applying technical knowledge to perform tasks effectively) and task habits (characteristic responses to task situations that either facilitate or hinder the performance of tasks) (Borman et.al, 2001).

Based on the literature review, we designed a study to examine the effect of psychological ownership on employee silence and task performance. Next section provides the research methodology, data collection procedure, hypotheses and data analyses. 


\section{Methodology}

\subsection{Research Objective}

This study aims to examine the effect of psychological ownership on employee silence and task performance. For this purpose, a field research is conducted on academicians working for state universities in Turkey.

\subsection{Sample and Data Collection}

Research data is collected by an online survey. Population of the study is consisted of academicians working for state universities in Turkey. In order to obtain a complete list of academicians working for state universities in Turkey, a secondary research is conducted by scanning the web pages of the universities. After picking up the e-mail addresses, an invitation containing the web link of the online survey is sent to 7266 academicians' email addresses from state universities located all over the country. Data collection process took place between December 2016 and February 2017 and 502 valid responses are collected at the end of the process.

The online survey contained the 7 item Psychological Ownership Scale (Van Dyne and Pierce, 2004); 15 item Employee Silence Scale developed by Van Dyne et.al. (2003) and 9 item Task Performance Scale (Booth-Butterfield and Booth-Butterfield, 1991). Responses are taken by 5 point ( $1=$ strongly disagree; $5=$ strongly agree) Likert type scales for all of the study variables.

\subsection{Research Model}

Research model and hypotheses are seen on Figure 1.

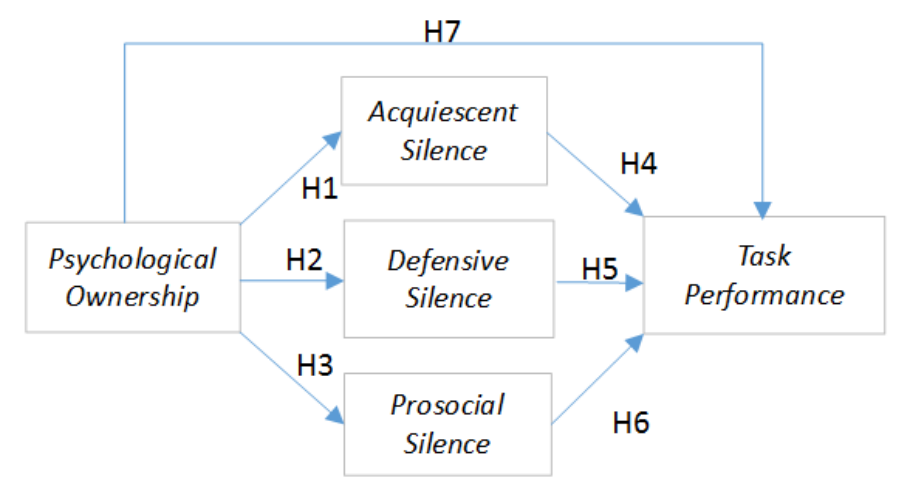

Figure 1. Proposed model

\section{Hypotheses}

Based on the literature review, following hypotheses are proposed about the relationships between psychological ownership, employee silence and task performance.

$H_{1}$ : Acquiescent silence negatively effects task performance.

$\mathrm{H}_{2}$ : Defensive silence negatively effects task performance.

$H_{3}$ : Pro-social silence positively effects task performance.

$H_{4}$ : Psychological ownership negatively effects acquiescent silence.

$H_{5}$ : Psychological ownership negatively effects defensive silence.

$H_{6}$ : Psychological ownership positively effects pro-social silence.

$H_{7}$ : Psychological ownership positively effects task performance.

\subsection{Analyses and Results}

502 valid responses were collected by an online questionnaire. $58,6 \%$ of the respondents were males and $41,4 \%$ were females. $18,1 \%$ were single and $81,9 \%$ were married at the time of data collection. $30,7 \%$ of the respondents were aged between $34-41$, whereas only $3,4 \%$ were older than $57.33,5 \%$ of the participants were lecturers, $2 \%$ were translators and experts. Data analysis was performed by using SPSS program.

Scale reliability was examined in terms of inter-item consistency and Cronbach's Alpha coefficients were calculated for each scale. In order to check scale dimensionality, all study variables were subjected to exploratory factor analysis (EFA). The sample seemed adequate for running the EFA (KMO = 0,912; Bartlett's 
test of spherecity $\mathrm{p}<0,001)$. Table 1 show the results of exploratory factor analysis (factor loadings) and reliability analyses (Cronbach Alpha coefficients) with the descriptive statistics including item means and standard de viations. Principal components analysis with varimax rotation suggested five factors which explained $65 \%$ of the total variance. All of the scale items loaded adequately on the corresponding factors. Cronbach's Alpha coefficients showed satisfactory reliability for each scale $(\min 0,743)$.

Table 1. Results of Exploratory Factor Analysis and Reliability Analyses

\begin{tabular}{|c|c|c|c|c|}
\hline & Mean & $\begin{array}{c}\text { Std. } \\
\text { Deviation }\end{array}$ & $\begin{array}{l}\text { Factor } \\
\text { Loading }\end{array}$ & $\begin{array}{l}\text { Cronbach's } \\
\text { Alfa }\end{array}$ \\
\hline \multicolumn{5}{|l|}{ Psychological Ownership } \\
\hline This is MY organization. & 3.77 & 1.167 & .884 & \multirow{7}{*}{.940} \\
\hline I sense that this organization is OUR company. & 3.65 & 1.203 & .900 & \\
\hline I feel a very high degree of personal ownership for this organization. & 3.48 & 1.234 & 905 & \\
\hline I sense that this is MY company. & 3.56 & 1.199 & .913 & \\
\hline This is OUR company. & 3.66 & 1.185 & .908 & \\
\hline $\begin{array}{l}\text { Most of the people that work for this organization feel as though they } \\
\text { own the company. }\end{array}$ & 2.93 & 1.042 & .628 & \\
\hline $\begin{array}{l}\text { It is hard for me to think about this organization as MINE. (reversed) } \\
\text { Acquiescent Silence }\end{array}$ & 3.78 & 1.251 & .623 & \\
\hline $\begin{array}{l}\text { I am unwilling to speak up with suggestions for change because I am } \\
\text { disengaged. }\end{array}$ & 2.88 & 1.280 & .720 & \multirow{5}{*}{.743} \\
\hline $\begin{array}{l}\text { I am unwilling to speak up with suggestions for change because I } \\
\text { believe that my colleagues will make the right decision. }\end{array}$ & 2.05 & .911 & .670 & \\
\hline I keep my ideas about solutions to problems to myself. & 1.97 & 1.082 & .425 & \\
\hline $\begin{array}{l}\text { I keep any ideas for improvement to myself because I have low } \\
\text { self-efficacy to make a difference. }\end{array}$ & 1.85 & 1.002 & .527 & \\
\hline $\begin{array}{l}\text { I am unwilling to express my ideas for change in disengaged areas } \\
\text { because I don't want to increase the work load. } \\
\text { Defensive Silence }\end{array}$ & 2.31 & 1.133 & .619 & \\
\hline $\begin{array}{l}\text { I withhold new information dues to fear about my future in the } \\
\text { organization. }\end{array}$ & 2.02 & 1.090 & .725 & \multirow{5}{*}{.906} \\
\hline I withhold relevant information due to fear. & 2.25 & 1.190 & .827 & \\
\hline I omit pertinent facts in order to protect him/her self. & 2.25 & 1.167 & .859 & \\
\hline I avoid expressing ideas for improvements, due to self-protection & 1.99 & 1.022 & .837 & \\
\hline I do not speak up and suggest ideas for change, based on fear & 1.97 & 1.111 & .773 & \\
\hline \multicolumn{5}{|l|}{ Pro-social Silence } \\
\hline I withhold confidential information, based on cooperation & 3.85 & 1.185 & .758 & \multirow{5}{*}{.876} \\
\hline I protect proprietary information in order to benefit the organization & 3.94 & 1.104 & .853 & \\
\hline I withstand pressure from others to tell organizational secrets. & 4.03 & 1.062 & .797 & \\
\hline I refuse to divulge information that might harm the organization & 4.09 & 1.075 & .828 & \\
\hline $\begin{array}{l}\text { Protects confidential organizational information appropriately, based on } \\
\text { concern for the organization. } \\
\text { Task Performance }\end{array}$ & 4.06 & 1.060 & .776 & \\
\hline Achieves the objectives of the job. & 3.69 & .937 & .550 & \multirow{9}{*}{.897} \\
\hline Meets criteria for performance. & 4.12 & .829 & .705 & \\
\hline Demonstrates expertise in all job-related tasks. & 4.25 & .792 & .763 & \\
\hline Fulfills all the requirements of the job. & 4.36 & .783 & .802 & \\
\hline Could manage more responsibility than typically assigned. & 4.16 & .890 & .742 & \\
\hline Appears suitable for a higher-level role. & 3.70 & .997 & .633 & \\
\hline Is competent in all areas of the job, handles tasks with proficiency. & 3.97 & .883 & .776 & \\
\hline Performs well in the overall job by carrying out tasks as expected. & 4.27 & .729 & .841 & \\
\hline Plans and organizes to achieve objectives of the job and meet deadlines. & 4.32 & .781 & .785 & \\
\hline
\end{tabular}

EFA and reliability analyses results verified the scale dimensionality and reliability. As a next step, composite measures were computed by averaging the responses on the corresponding items under each scale. Consequently, we computed five composite variables in order to be used to test the research hypotheses. Correlations among these composite variables are seen on Table 2. 
Table 2. Bivariate Correlations

\begin{tabular}{lcccc}
\hline & $\begin{array}{c}\text { Psychological } \\
\text { Ownership }\end{array}$ & $\begin{array}{c}\text { Acquiescent } \\
\text { Silence }\end{array}$ & $\begin{array}{c}\text { Defensive } \\
\text { Silence }\end{array}$ & Pro-social Silence \\
\hline Acquiescent Silence &,$- 319(* *)$ & & & \\
Defensive Silence &,$- 435(* *)$ &, $609(* *)$ &,- 007 &, $287(* *)$ \\
Pro-social Silence &, $179(* *)$ &,- 084 &,$- 144(* *)$ & \\
Task Performance &, $278(* *)$ &,$- 235(* *)$ & &
\end{tabular}

$* * \mathrm{P}<0.01$

$* \mathrm{P}<0.05$

Based on the bivariate correlation analyses, defensive silence and acquiescent silence are found to share significantly negative correlations with psychological ownership $(r=-0,435$ and $r=-0,319$ respectively, $p<0,001)$. Pro-social silence is found to have a significantly positive correlation with psychological ownership ( $r=0,278$, $\mathrm{p}<0,001)$. Similar results are obtained about the relationship between employee silence dimensions and task performance. Defensive silence and acquiescent silence are found to have significantly negative correlations with task performance ( $r=-0,144$ and $r=-0,235$ respectively, $p<0,001)$. Pro-social silence is found to have a significantly positive correlation with task performance $(r=0,287, p<0,001)$. Further, a significantly positive relationship between psychological ownership and task performance is found $(r=0,278 ; p<0,001)$. These findings exert significant interactions between the study variables. However, weak to moderate correlations among the study variables do not pose a multicollinearity risk for the regression analyses in the next step.

\subsection{Hypotheses Testing}

Research hypotheses were tested by a number of multiple regression analyses. Table. 3 shows the results of the first regression analysis where employee silence predicts task performance. According to regression analysis results, employee silence is a significant predictor of task performance $(\mathrm{F}=29,157 ; \mathrm{P}<0,001)$.

Table 3. Regression Analysis: The Effect of Employee Silence on Task Performance

\begin{tabular}{|c|c|c|c|c|c|c|c|}
\hline Model & $\begin{array}{c}\text { Independent Variable and } \\
\text { The Moderator }\end{array}$ & Stand. $\beta$ & $\mathrm{t}$ & Sig. & $\begin{array}{c}\text { Adjusted } \\
\mathrm{R}^{2}\end{array}$ & F Value & $\begin{array}{c}\text { Model } \\
\text { Sig. }\end{array}$ \\
\hline \multirow[t]{4}{*}{1} & Employee Silence & & & & .055 & 29.157 & .000 \\
\hline & Acquiescent Silence & -.235 & -5.400 & .000 & & & \\
\hline & Defensive Silence & -.144 & -3.263 & .001 & & & \\
\hline & Pro-social Silence & .287 & 6.693 & .000 & & & \\
\hline
\end{tabular}

Dependent Variable: Task Performance

$* * \mathrm{P}<0.01$

$* \mathrm{P}<0.05$

Acquiescent Silence and Defensive Silence have significantly negative effects on task performance $(\beta=-, 235$, $\mathrm{p}<0,001$ and $\beta=-, 144, \mathrm{p}<0,005$ respectively) Pro-social Silence has a significantly positive effect on task performance $(\beta=, 287, p<0,001)$. These findings support H1, H2, and H3. Acquiescent silence and defensive silence have negative effects on task performance while pro-social silence has a positive effect.

Table.4 shows the results of the second regression analysis where psychological ownership predicts acquiescent silence. According to regression analysis results, psychological ownership is a significant predictor of acquiescent silence $(\mathrm{F}=56,688, \mathrm{P}<0,001)$. Psychological ownership has a significantly negative effect on acquiescent silence $(\beta=-, 319, \mathrm{p}<0,001)$. Based on this finding, we support the fourth hypothesis $(\mathrm{H} 4)$. Psychological ownership has a negative effect on acquiescent silence.

Table 4. Regression Analysis: The Effect of Psychological Ownership on Acquiescent Silence

\begin{tabular}{clcccccc}
\hline Model & $\begin{array}{l}\text { Independent Variable } \\
\text { and The Moderator }\end{array}$ & Stand. $\beta$ & $\mathrm{t}$ & $\mathrm{Sig}$. & $\begin{array}{c}\text { Adjusted } \\
\mathrm{R}^{2}\end{array}$ & $\begin{array}{c}\text { F Value } \\
\text { Sig. }\end{array}$ & $\begin{array}{c}\text { Model } \\
\text { Psychological }\end{array}$ \\
\hline & -.319 & -7.529 & .000 & .100 & 56.688 & .000 \\
\hline
\end{tabular}

\footnotetext{
Dependent Variable: Acquiescent Silence

$* * \mathrm{P}<0.01$

* $\mathrm{P}<0.05$
} 
Table.5 shows the results of the third regression analysis where psychological ownership predicts defensive silence. According to regression analysis results, psychological ownership is a significant predictor of defensive silence $(\mathrm{F}=116,365, \mathrm{P}<0,001)$. Psychological ownership has a significantly negative effect on defensive silence $(\beta=-, 435, p<0,001)$. Based on this finding, we support the fifth hypothesis (H5). Psychological ownership has a negative effect on acquiescent silence.

Table 5. Regression Analysis: The Effect of Psychological Ownership on Defensive Silence

\begin{tabular}{clcccccc}
\hline Model & $\begin{array}{c}\text { Independent Variable } \\
\text { and The Moderator }\end{array}$ & Stand. $\beta$ & $\mathrm{t}$ & Sig. & $\begin{array}{c}\text { Adjusted } \\
\mathrm{R}^{2}\end{array}$ & F Value & $\begin{array}{c}\text { Model } \\
\text { Sig. }\end{array}$ \\
\hline 1 & $\begin{array}{l}\text { Psychological } \\
\text { Ownership }\end{array}$ & -.435 & -10.787 & .000 & .187 & 116.365 & .000 \\
\hline
\end{tabular}

Dependent Variable: Defensive Silence

$* * \mathrm{P}<0.01$

$* \mathrm{P}<0.05$

Table.6 shows the results of the fourth regression analysis where psychological ownership predicts pro-social silence. According to regression analysis results, psychological ownership is a significant predictor of pro-social silence $(\mathrm{F}=16,477, \mathrm{P}<0,001)$. Psychological ownership has a significantly positive effect on pro-social silence $(\beta=, 179, p<0,001)$. Based on this finding, we support the sixth hypothesis (H6). Psychological ownership has a positive effect on pro-social silence.

Table 6. Regression Analysis: The Effect of Psychological Ownership on Pro-social Silence

\begin{tabular}{clcccccc}
\hline Model & $\begin{array}{c}\text { Independent Variable } \\
\text { and The Moderator }\end{array}$ & Stand. $\beta$ & $\mathrm{t}$ & Sig. & $\begin{array}{c}\text { Adjusted } \\
\mathrm{R}^{2}\end{array}$ & F Value & $\begin{array}{c}\text { Model } \\
\text { Sig. }\end{array}$ \\
\hline 1 & $\begin{array}{l}\text { Psychological } \\
\text { Ownership }\end{array}$ & .179 & 4.059 & .000 & .030 & 16.477 & .000 \\
\hline
\end{tabular}

Dependent Variable: Pro-social Silence

$* * \mathrm{P}<0.01$

$* \mathrm{P}<0.05$

Finally, Table 7 shows the results of the last regression analysis where psychological ownership predicts task performance. According to regression analysis results, psychological ownership is a significant predictor of task performance $(\mathrm{F}=41,723, \mathrm{P}<0,001)$. Psychological ownership has a significantly positive effect on task performance $(\beta=, 278, \mathrm{p}<0,001)$. Based on this finding, we support the last hypothesis $(\mathrm{H} 7)$. Psychological ownership has a positive effect on task performance.

Table 7. Regression Analysis: The Effect of Psychological Ownership on Task Performance

\begin{tabular}{clcccccc}
\hline Model & $\begin{array}{l}\text { Independent Variable } \\
\text { and The Moderator }\end{array}$ & Stand. $\beta$ & $\mathrm{t}$ & Sig. & $\begin{array}{c}\text { Adjusted } \\
\mathrm{R}^{2}\end{array}$ & $\begin{array}{c}\text { F Value } \\
\text { Sig. }\end{array}$ \\
\hline $\begin{array}{l}\text { Psychological } \\
\text { Ownership }\end{array}$ & .278 & 6.459 & .000 & .077 & 41.723 & .000 \\
\hline
\end{tabular}

Dependent Variable: Task Performance

** $\mathrm{P}<0.01$

$* \mathrm{P}<0.05$

\section{Discussion}

This study aimed to contribute the literature by examining the effect of psychological ownership (as perceived by the employees) on employee silence and task performance. In today's turbulent work environment, high uncertainty, organizational downsizing, mergers and other trends raised the importance of employee performance in achieving organizational goals. Thus, it is vital for organizations to know their employees profoundly. (Eisenberger et.al. 2016; Kurtessis et.al., 2015).

Psychological ownership has positive outcomes for the organization and it may urge emotional, attitudinal and behavioral consequences (Van Dyne \& Pierce, 2004). Employee performance is positively affected by the perception of high organizational support (Kurtessis et.al 2015; Rhoades \& Eisenberger, 2002). At this stage it is important to relay maximum employee contribution to the organization. However, when employees do not provide feedback about the problems they observe, the phenomenon "employee silence" comes to existence (Morrison, 2014). In this case, before informing their managers, expressing ideas or speaking about a problem, employees pay attention to whether their managers will take responsibility and stand by them (Milliken et.al., 2003). 
Firstly, this study examined the effect of psychological ownership on different dimensions of employee silence. Data analyses revealed significant relationships between psychological ownership and employee silence. According to the results, as psychological ownership increase, acquiescent silence and defensive silence decrease, while pro-social silence increase. These findings are consistent with the previous findings indicating that psychological ownership is an antecedent of employee silence. When employees feel comfortable and open communication channels are available in the organization, this leads employees to feel psychologically safe (Botero \& Van Dyne, 2009).

Secondly, the effect of employee silence dimensions on task performance was probed. Results showed that as acquiescent silence and defensive silence increase, task performance decreases. On the other hand, as pro-social silence increase, task performance also increases. These findings are also consistent with the relevant literature. Brinsfield et.al. (2009) found that employee voice and silence significantly influence employee and organizational performance. Other researchers documented similar results about the negative effects of acquiescent silence and defensive silence on task performance; and the positive effect of pro-social silence on task performance (Briensfield et.al., 2009, Tayfun \& Çatır 2013).

Finally, the relationship between psychological ownership and task performance was examined. Results showed that as the level of perceived psychological ownership increase, task performance also increases. Indeed, studies show when organizations back up their employees psychologically, employee level outputs are promoted and their performance increased (Ghafoor et.al., 2011; Sieger et.al., 2013). Similarly, Van Dyne and Pierce, (2004) claimed that psychological ownership is the key component of increased organizational performance and organizational citizenship.

\section{Conclusion}

This study provides some empirical evidence about the effect of psychologic al ownership on employee silence and task performance. The empirical findings obtained by this study highlight the importance of the feeling of psychological ownership in the organizations as a critical factor that may affect the employer-employee relationship and their mutual responsibilities. Expressing their innovative ideas and suggestions in a supportive work environment, academicians may improve their performance and keep up with the fast-changing science and education industry. Particularly working in state universities where organizational hierarchy is relatively high, managerial attitudes and behavior have significant influence on the productivity of academicians. If they feel that their efforts are not well appreciated, they will respond with negative emotions and prefer keeping silent rather than sharing their expertise and experience to improve organizational performance.

This study has a number of limitations. First, this study is limited with the data collected only from academicians working for the state universities. Higher education industry is a unique sector that has particular work conditions. Hence, replicating this study in a different context may reveal additional insights. Another limitation is keeping perceived psychological ownership as the only antecedent of employee silence. In the real life settings, several other factors may contribute to employee silence. Future studies may integrate other work related / organizational factors that may influence employee silence into the model. Further, possible variations caused by employee demographics and working conditions may also be controlled in future studies.

\section{References}

Avey, J. B., Avolio, B. J., Crossley, C. D., \& Luthans, F. (2009). Psychological ownership: theoretical entensions, measurement and relation to work outcomes. Journal of Organizational Behavior, 30, 173-191. https://doi.org/10.1002/job.583

Booth-Butterfield, M., \& Booth-Butterfield S. (1991). Individual differences in the communication of humorous messages., Southern Communication Journal 56(3), 205-218. https://doi.org/10.1080/10417949109372831

Borman, W. C., \& Motowidlo, S. J. (1993). Expanding the criterion domain toinclude elements of contextual performance. Chapter in N. Schmitt and W. C. Borman (Eds.), Personnel Selection. San Francisco: Josey-Bass, 71-98.

Borman, W. C., \& Motowidlo, S. J. (1997). Task performance and contextual performance: the meaning for personnel selection research. Human Performance, 10, 99-109. https://doi.org/10.1207/s15327043hup1002_3

Borman, W. C., Penner, L. A., Allen, T. D., \& Motowidlo, S. J. (2001). Personality predictors of citizenship performance. International Journal of Selection and Assessment, 9(1-2), 52-69. https://doi.org/10.1111/1468-2389.00163 
Botero, I. C., \& Van Dyne, L. (2009). Predicting voice: Interactive effects of LMX and power distance in the U.S. and colombia. Management Communication Quarterly, 23, 84-104. https://doi.org/10.1177/0893318909335415

Brinsfield, C. T., Edwards M. S., \& Greenberg J. (2009). Voice and silence in organizations: historical review and current conceptualizations, Voice and Silence in Organizations Chapter 1, Emerald Group Publishing Limited, First Edition, UK, 3-33.

Çakıcı, A. (2007). Örgütlerde sessizlik: sessizliğin teorik temelleri ve dinamikleri, Ç.Ü. Sosyal Bilimler Enstitüsü Dergisi, 16(1), $145-162$.

Dittmar, H. (1992). The social psychology of material possessions: to have is to be. Hemel Hempstead: Harvester Wheatsheaf.

Eisenberger, R., Glenn P. M., \& William, D. (2016). Optimizing perceived organizational support to enhance employee engagement. Society for Human Resource Management and Society for Industrial and Organizational Psychology.

Ghafoor, A., Qureshi, T. M., Khan, M. A., \& Hijazi, S. T. (2011). Transformational leadership, employee engagement and performance: Mediating effect of psychological ownership. African journal of business management, 5(17), 7391-7403. https://doi.org/10.5897/AJBM11.126

Hirschman, A. O. (1970). Exit, voice and loyalty: Responses to decline in firms, Organizations, and States. Cambridge, London: Harvard University Press.

Jawahar, I. M., \& Carr, D. (2007). Conscientiousness and contextual performance: the compensatory effects of perceived organizational support and leader - member exchange. Journal of Managerial Psychology, 22(4), 330-349. https://doi.org/10.1108/02683940710745923

Kurtessis, J. N., Eisenberger, R., Ford, M. T., Buffardi, L. C., Stewart, K. A., \& Adis, C. S. (2015). Perceived organizational support: a meta-analytic evaluation of organizational support theory. Journal of Management, 20(10), 1-31.

Li, R., \& Ling, W. (2010). The impact of perceived supervisor support on employe es work - related attitudes and silence. Behavior Journal of Business Economics, 5, 7.

Mayhew, M. G., Ashkanasy, N. M., Bramble, T., \& Gardner, J. (2007). A study of the antecedents and consequences of psychological ownership in organizational settings. The Journal of social psychology, 147(5), 477-500. https://doi.org/10.3200/SOCP.147.5.477-500

Milliken, F. J., Morrison E. W., \& Hewlin, P. F. (2003). An exploratory study of employee silence: issues that employees don't communicate upward and why. Journal of Management Studies, 40(6), 1453-1476. https://doi.org/10.1111/1467-6486.00387

Morrison, E. W., \& Milliken, F. J. (2000). Organizational silence: a barrier to change and de velopment in a pluralistic. The Academy Of Management Review, 25, 706-725.

Morrison, E. W., \& Milliken, F. J. (2003). Speaking up, remaining silent: the dynamics of voice and silence in organizations. Journal of Management Studies, 40(6), 1353-1358. https://doi.org/10.1111/1467-6486.00383

Morrison, E. W. (2014). Employee voice and silence. Annual Review Of Organizational Psychology And Organizational Behavior, 1, 173-197. https://doi.org/10.1146/annurev-orgpsych-031413-091328

Murphy, K. R., \& Cleveland, J. N. (1995). Understanding performance appraisal: social, organizational and goal based perspectives. Thousand Oaks, CA: Sage.

Perlow, L. A., \& Williams, S. (2003). Is silence killing your company? Harward Business Review, 31(4), 18-23. https://doi.org/10.1109/EMR.2003.24935

Pierce, J. L., \& Furo, C. A. (1991). Employee ownership: Implications for management. Organizational Dynamics, 18(3), 32-43. https://doi.org/10.1016/0090-2616(90)90062-T

Pierce, J. L., Kostova, T., \& Dirks, K. T. (2001). Toward a theory of psychological ownership in organizations. Academy of Management Review, 26(2), 298-310.

Pierce, J. L., Rubenfeld, S. A., \& Morgan, S. (1991). Employee ownership: a conceptual model of process and effects. Academy of Management Review, 16, 121-144. https://doi.org/10.5465/AMR.1991.4279000

Pinder, C. C., \& Harlos K. P. (2001). Quiescence and acquiescence as pesponses to perce1ved injustice. Research in Personnel and Human Resources Management, 20, 331-369. 
Rhoades, L., \& Eisenberger, R. (2002). Perceived organizational support: a review of the literature. Journal of Applied Psychology, 87, 698-714. https://doi.org/10.1037/0021-9010.87.4.698

Rodgers, L. (1998). Participation: decision making and employee ownership. The ownership culture report, 1 (2), $1-4$.

Rotundo, M., \& Sackett, P. R. (2002). The relative importance of task, citizenship, and counterproductive performance to global ratings of job performance: a policy-capturing approach. Journal of Applied Psychology, 87, 66 - 80. https://doi.org/10.1037/0021-9010.87.1.66

Schlenker, B. R., \& Weigold, M. F. (1989). Self-İdentification and accountability, in giacalone. R. A. and Rosenfeld, P. (Ed.), Impression Management İn The Organization. Hillsdale, NJ: Erlbaum, 21-43.

Sieger, P., Zellweger, T., \& Aquino, K. (2013). Turning agents into psychological principals: aligning interests of non-owners through psychological ownership. Journal of Management Studies, 50(3), 361-388. https://doi.org/10.1111/joms.12017

Tayfun, A., \& Çatır, O. (2013). Örgütsel sessizlik ve çalışanların performansları arasındaki ilişki üzerine bir araştırma. İsletme Araştırmaları Dergisi, 114-134.

Van Dyne, L., \& Pierce, J. L. (2004). Psychological ownership and feelings of possession: three field studies predicting employee attitudes and organizational citizenship behavior. Journal of Organizational Behavior, 25(4), 439-459. https://doi.org/10.1002/job.249

Van Dyne, L., Soon, A., \& Botero, I. C. (2003). Conceptualizing employee silence and employee voice as multidimensional constructs. Journal of Management Studies, 40(6), 1359-1392. https://doi.org/10.1111/1467-6486.00384

Vokola, M., \& Bouradas, D. (2005). Antecedents and consequences of organizational silence: an empirical investigation. Employee Relations, 27, 441-458. https://doi.org/10.1108/01425450510611997

\section{Copyrights}

Copyright for this article is retained by the author(s), with first publication rights granted to the journal.

This is an open-access article distributed under the terms and conditions of the Creative Commons Attribution license (http://creativecommons.org/licenses/by/4.0/). 